\title{
A Study on Present Shanghai Urban Inhabitants' Leisure Activities and Sites
}

\author{
Yangle Song*1 and Takayuki Ikeda ${ }^{2}$ \\ ${ }^{1}$ Doctoral Graduate Student, Faculty of Engineering, University of the Ryukyus, Japan \\ ${ }^{2}$ Professor, Faculty of Engineering, University of the Ryukyus, Japan
}

\begin{abstract}
This study was initiated to clarify the significance of urban green open space by obtaining data on, and illustrating details concerning Shanghai urban inhabitants' daily leisure activities and sites. The authors have carried out a small-scale questionnaire around People's Square in Shanghai, with this topic as its focus. The method of the questionnaire was that of an objective spot check. The authors have carried out some statistical work and analyzed the data as follows: interviewee's age, gender, occupation, educational level, daily leisure time, leisure categories, leisure sites, reasons for choices, motivation of leisure, and main opinions regarding outdoor leisure sites. Finally, the authors have drawn the following conclusions: Present Shanghai urban inhabitants have relatively adequate daily leisure time and disposable income, but the categories of leisure activities are small and most of them are traditional and static in form. Compared to western developed countries, the leisure standards of Shanghai urban inhabitants are still in the early stages, and the present number of outdoor leisure sites are too few. The distribution of these sites within the city is poor, outdoor leisure sites should be low in cost or free, and with public green open space as the most popular type, afforestation efforts should be greatly enhanced in Shanghai. The designers of the sites should take into account differences in age among the users, and the management and maintenance systems should also be perfected.
\end{abstract}

Keywords: leisure activities and sites; questionnaire; urban inhabitants; green open space; people's square Shanghai

\section{Introduction}

\subsection{Background and purpose}

Since the 1980's, Chinese society has undergone tremendous reformation. The high-speed increase of economic activity has pushed all other aspects of society into a boom period. With Shanghai being the biggest metropolis of China; its urban planning work was facing unheard-of challenges. Closely correlated with the mental and physical health of urban inhabitants, daily leisure reflected the tendencies and requirements of social developments. Focusing on the daily leisure activities and sites of Shanghai urban inhabitants, the purpose of this study is to clarify the significance of urban green open space, by obtaining data on, and illustrating details concerning their daily leisure activities and sites.

Previous research has been carried out on the topic of leisure related to health, medical treatment, life style and tourism, etc, but the studies that are close to our topic are as follows: The Free Time and Leisure Participation Study (Grant C., A. J. Veal, Jiri Z. 2004) and The Research and Design on Urban Leisure Environment Study (Ma Jianye, 2002). The former has

*Contact Author: Yangle Song, Graduate School of Engineering \& Architecture, University of the Ryukyus, 1 Senbaru, Nishihara-cho, Okinawa Pref., 903-0213, Japan Tel: +81-98-895-8901 Fax: +81-98-895-8901

E-mail: xiaobaill_jp@yahoo.co.jp

(Received May 10, 2005 ; accepted August 31, 2005)

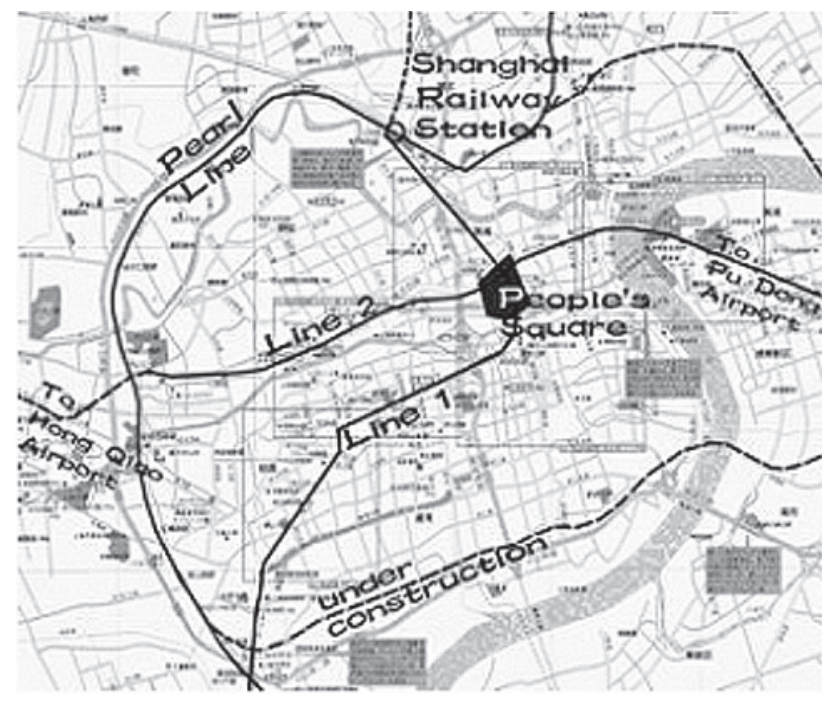

Fig.1. The Location of People's Square in Shanghai

analyzed the statistics of the general leisure situation of 15 countries such as the US, UK, Canada and France, etc. The latter was completed by Chinese researchers and focused on the daily and noncommercial leisure environment of four cities in Northern China such as Beijing, Shengyang, etc.

Taking the Shanghai urban inhabitants' leisure situation as its subject for research, this study is the first of its kind for this geographical region. By studying former research methods and experience, this study has enriched relative research outcomes and is of 
certain referential value for future studies in the fields of leisure, urban space, social health and welfare work, etc, of Shanghai and China.

\subsection{Study Methods}

Aimed at the daily leisure activities and leisure sites of present Shanghai urban inhabitants, the data for this study was gathered in the area around People's Square, in Shanghai. The questionnaire was carried out at this site for the following reasons:

(1) Shanghai is the biggest city in China and is a leader in Chinese innovation in many industries; it also represents the trends of Chinese urban leisure. The level of the leisure sites and facilities there are the most advanced in China.

(2) Considering the study's shortage of interviewees, and out of a desire to make the questionnaire as accurate as possible, the authors chose the People's Square of Shanghai. This site was chosen because it is the biggest traffic hinge in Shanghai (Fig.1.), located in the center of the city; tremendous streams of people from all parts of Shanghai (even from the whole country) can be found here. This condition assures that the coverage of the questionnaire will be extensive.

The questionnaire was carried out in November 2004. The interviewer distributed, inquired and gathered altogether 104 questionnaires on the spot. The rate of validity is $100 \%$. Objective spot check is a method of investigation which will ensure a wellproportioned distribution of the samples, by the interviewer selecting the interviewee. In a spot check, fluctuations in proportion are more convincing than absolute figures.

Table 1. Urban Inhabitants' Consumption Structure

\begin{tabular}{|c|c|c|c|c|c|c|c|c|}
\hline Year & Food & Clothes & $\begin{array}{c}\text { Home } \\
\text { appliances }\end{array}$ & $\begin{array}{c}\text { Medical/ } \\
\text { health }\end{array}$ & Correspondence & $\begin{array}{c}\text { Education/culture; } \\
\text { recreation/service }\end{array}$ & Housing & Others \\
\hline 1980 & 56.0 & 14.3 & 9.0 & 1.3 & 3.6 & 8.9 & 4.8 & 2.1 \\
\hline 1990 & 56.5 & 10.8 & 10.1 & 0.6 & 3.0 & 11.9 & 4.6 & 2.5 \\
\hline 1995 & 53.4 & 9.6 & 10.9 & 1.9 & 5.5 & 8.6 & 6.8 & 3.3 \\
\hline 1999 & 45.2 & 6.7 & 9.3 & 4.2 & 7.1 & 13.3 & 10.2 & 4.0 \\
\hline 2001 & 43.4 & 6.2 & 6.2 & 6.0 & 10.3 & 15.2 & 8.5 & 4.2 \\
\hline 2003 & 37.2 & 6.8 & 7.2 & 5.4 & 11.4 & 16.6 & 11.6 & 3.8 \\
\hline
\end{tabular}

Data source: Shanghai Statistical Almanac, 2004

\section{A primary survey on Chinese leisure}

\subsection{History of Leisure in China: A Retrospection}

The first literary record of leisure in China can be found in the Spring and Autumn Period, within Confucius's "six abilities": manners, music, toxophily, drive, calligraphy and math. In addition, there are examples in some of the Ming and Qing Dynasty's novels such as: musical instruments, chess, painting and calligraphy (flowers, bird, insect and fish, etc). All of the above are luxuries to the common people. From this point of view, in ancient China daily leisure was a kind of privilege, especially for the scholar-bureaucrat hierarchy. At the time the common people had only festivals and daily games for children as sources of leisure activity.

In the late Qing dynasty, with the introduction of western religion, the word "Sunday" appeared in China. After the Xinhai Revolution of 1911, Sunday began to be known as a day of rest. However, untill the 1980's, leisure was still an accessory of labor for Chinese people. During this time, Chinese leisure was social and collective. Personal individuality and hobbies were seldom considered.

Since the opening and rapid development of China, along with continual economic growth, the Chinese people as a whole have come to know an increase in time and available disposable income for leisure activities. (Table 1.) The average total expenditure of an urban inhabitant in 2003 has extended to 11,040 $\mathrm{RMB}$, of which the consumption related to leisure was 1,834 RMB. Also, in the social environment the concept of "Leisure" was popularized among the people. Moreover, the Chinese government has been enforcing Labor Laws ${ }^{1}$ to ensure that the people receive the proper amount of leisure time. For example: From May $1^{\text {st }}, 1995$, the government instituted a nationwide "5-day work week" policy, with an 8-hour work day, which ammounts to a 40-hour work week. This increased the common people's leisure time dramatically; especially with China's large ageing population. All of these factors have spurred a sharp increase in the leisure requirements of the Chinese people.

\subsection{Leisure categories}

As for the categories of leisure activities, let's have a look at the tables below. The data from Hong Kong is nearly 10 -years old, but is still a valid reference for present-day Shanghai.

There are many leisure activities in the tables above. For the convenience of research, we have sorted them into categories (Table 4.). They have been sorted according to subject, function, consumption level, etc.

\section{Leisure Consciousness of Shanghai Urban Inhabitants}

\subsection{General Information of the Interviewee}

Tables. 5-7 contain some basic information about the interviewees. All the data is displayed uniformly to clearly show the status quo.

In Table 5., we divided the interviewees into 5 age groups respectively: Children, Adolescents, Young Adults, Mature Adults, and the Elderly. Thereupon, 
Table 2. Leisure Activities of Hong Kong by Age in 1993

\begin{tabular}{|c|c|c|c|c|c|c|c|c|c|}
\hline \multirow[b]{2}{*}{ Leisure activities } & \multicolumn{9}{|c|}{ Age } \\
\hline & $6 \sim 11$ & $12 \sim 16$ & $17 \sim 18$ & $19 \sim 24$ & $25 \sim 34$ & $35 \sim 44$ & $45 \sim 54$ & $55 \sim 64$ & 65 \\
\hline Watching TV & 62.1 & 58.4 & 65.7 & 41.6 & 59.8 & 55.0 & 55.6 & 53.3 & 72.7 \\
\hline Shopping & 43.5 & 42.5 & 31.5 & 29.0 & 44.5 & 47.4 & 37.4 & 30.0 & 54.5 \\
\hline Visiting a library & 60.4 & 47.9 & 48.9 & 48.5 & 23.8 & 22.4 & 19.3 & 10.0 & 9.1 \\
\hline Dining out & 29.2 & 27.1 & 23.6 & 42.4 & 40.2 & 42.8 & 36.9 & 23.3 & 27.3 \\
\hline Broadcast and music & 21.2 & 38.9 & 51.7 & 37.2 & 20.1 & 19.9 & 17.6 & 26.7 & 36.4 \\
\hline Newspaper/magazine & 14.9 & 19.3 & 27.5 & 29.9 & 36.6 & 43.3 & 41.7 & 43.3 & 27.3 \\
\hline Watching a movie & 18.0 & 34.0 & 35.4 & 53.7 & 34.1 & 17.9 & 10.2 & 6.7 & 0.0 \\
\hline Playing PC games & 41.3 & 40.8 & 29.8 & 16.9 & 8.5 & 5.9 & 2.7 & 3.3 & 0.0 \\
\hline Going to a cafe & 18.8 & 14.4 & 9.0 & 17.7 & 26.8 & 32.4 & 36.4 & 46.7 & 45.5 \\
\hline Picnic & 22.1 & 19.8 & 16.9 & 18.2 & 14.6 & 19.0 & 17.1 & 10.0 & 9.1 \\
\hline Karaoke & 15.2 & 21.0 & 23.6 & 30.3 & 25.6 & 12.9 & 9.6 & 6.7 & 18.2 \\
\hline Walking in a park & 19.9 & 11.0 & 6.7 & 7.8 & 14.6 & 23.1 & 27.3 & 23.3 & 36.4 \\
\hline
\end{tabular}

Data source: Sivan and Robertson, 1993

Table 3. General Leisure Activities of Hong Kong in 1993

\%per Person

\begin{tabular}{|c|c|c|c|c|c|}
\hline Leisure activities & $\begin{array}{c}\text { Percent of } \\
\text { participation }\end{array}$ & Leisure activities & $\begin{array}{c}\text { Percent of } \\
\text { participation }\end{array}$ & Leisure activities & $\begin{array}{l}\text { Percent of } \\
\text { participation }\end{array}$ \\
\hline Watching TV & $57.2 \%$ & Walk in a park & $16.9 \%$ & Pop concert & $4.0 \%$ \\
\hline Shopping & $41.7 \%$ & Reading & $16.1 \%$ & Volunteer & $3.3 \%$ \\
\hline Visiting a library & $40.6 \%$ & Chess and cards & $14.8 \%$ & Classical concert & $2.3 \%$ \\
\hline Dining out & $33.2 \%$ & Relaxing & $13.9 \%$ & Flying a kite & $2.0 \%$ \\
\hline Broadcast/tape & $29.9 \%$ & Staying at home & $10.8 \%$ & Theater going & $2.0 \%$ \\
\hline Watching a movie & $27.7 \%$ & Visiting a museum & $8.4 \%$ & Opera house & $1.6 \%$ \\
\hline Playing PC games & $25.8 \%$ & Course study & $5.9 \%$ & Disco & $1.1 \%$ \\
\hline Going to a cafe & $21.5 \%$ & Religion & $5.8 \%$ & Body building & $0.9 \%$ \\
\hline Picnic & $19.1 \%$ & Art & $5.6 \%$ & Night club & $0.4 \%$ \\
\hline Karaoke & $18.6 \%$ & Horse racing & $4.6 \%$ & \multirow{2}{*}{$\begin{array}{l}\text { Community } \\
\text { activities }\end{array}$} & \multirow{2}{*}{$1.8 \%$} \\
\hline Newspaper/magazine & $27.8 \%$ & Playing musical instrument & $7.6 \%$ & & \\
\hline
\end{tabular}

Data source: Sivan and Robertson, 1993

Table 4. Leisure Categories

\begin{tabular}{|c|c|c|c|}
\hline \multirow{2}{*}{ Categories } & \multicolumn{3}{|c|}{ Assorting criterion } \\
\cline { 2 - 4 } & Subject & Function & Consumption level \\
\hline & $\begin{array}{c}\text { Indoor } \\
\text { leisure, } \\
\text { Outdoor } \\
\text { leisure }\end{array}$ & $\begin{array}{c}\text { Static/passive } \\
\text { leisure, } \\
\text { Dynamic/positive } \\
\text { leisure }\end{array}$ & $\begin{array}{c}\text { Urban daily } \\
\text { leisure, Suburb } \\
\text { weekly leisure, } \\
\text { Regional seasonal } \\
\text { leisure }\end{array}$ \\
\hline
\end{tabular}

we selected the age of 22 as the dividing line between the Adolescent and Young Adult age groups, not the standard adult age of 18 or 21 of western countries. This is because the average Chinese college students' graduation age is 22 . Before 22 , most young people are still college students; their daily life is very different from that of the average socialite. Dividing this age group will be more helpful for later studies.

Table 6. is about the interviewees' occupation. We originally planned to have more detailed categories for the occupations, but in reality, we found that some people refused to answer the questions referring to their private information. Therefore, the occupational categories were separated as follows: Mental work, Physical work and Retired/jobless.

Through the 3 Tables above, we could determine the following: The majority of the interviewees were composed of young adults (23 40 years old), in the mental work occupational category, at the middle-
Table 5. Interviewee Age Information

\begin{tabular}{|lr|rrrrr|}
\hline \multirow{2}{*}{ Amount } & \multicolumn{5}{|c|}{ Age Groups $^{3}$} \\
\cline { 3 - 7 } & & $<15$ & $15 \sim 22$ & $23 \sim 40$ & $41 \sim 60$ & $>60$ \\
\hline Male & 51 & 2 & 3 & 23 & 13 & 10 \\
Female & 53 & 1 & 7 & 22 & 14 & 9 \\
Total & 104 & 3 & 10 & 45 & 27 & 19 \\
\hline \multicolumn{2}{|c|}{\begin{tabular}{l} 
Proportion \\
\multicolumn{2}{|c|}{$100 \%$}
\end{tabular}} & $2.9 \%$ & $9.6 \%$ & $43.3 \%$ & $26 \%$ & $18.2 \%$ \\
\hline
\end{tabular}

Table 6. Interviewee Occupation Information

\begin{tabular}{|lr|ccc|}
\hline \multirow{2}{*}{ Amount } & \multicolumn{3}{|c|}{ Occupation } \\
\cline { 2 - 5 } & $\begin{array}{c}\text { Mental } \\
\text { work }\end{array}$ & $\begin{array}{l}\text { Physical } \\
\text { work }\end{array}$ & $\begin{array}{c}\text { Retired } \\
\text { /jobless }\end{array}$ \\
\hline Male & 51 & 32 & 8 & 11 \\
Female & 53 & 26 & 14 & 13 \\
Total & 104 & 58 & 22 & 24 \\
\hline \multicolumn{2}{|c|}{\begin{tabular}{c} 
Proportion \\
\multicolumn{2}{|c|}{$100 \%$}
\end{tabular}} & $55.8 \%$ & $21.1 \%$ & $23.1 \%$ \\
\hline
\end{tabular}

Table 7. Interrviewee Education Information

\begin{tabular}{|c|c|c|c|c|}
\hline \multirow{2}{*}{\multicolumn{2}{|c|}{ Amount }} & \multicolumn{3}{|c|}{ Education level } \\
\hline & & \multirow{2}{*}{$\begin{array}{c}\begin{array}{c}\text { Junior } \\
\text { high school }\end{array} \\
8\end{array}$} & \multirow{2}{*}{$\begin{array}{c}\begin{array}{c}\text { Senior } \\
\text { high school }^{*}\end{array} \\
24\end{array}$} & \multirow{2}{*}{$\begin{array}{c}\begin{array}{c}\text { College } \\
\text { or higher }\end{array} \\
19\end{array}$} \\
\hline Male & 51 & & & \\
\hline Femal & 53 & 5 & 34 & 14 \\
\hline Total & 104 & 13 & 58 & 33 \\
\hline \multicolumn{2}{|c|}{$\begin{array}{c}\text { Proportion } \\
100 \%\end{array}$} & $12.5 \%$ & $55.8 \%$ & $31.7 \%$ \\
\hline
\end{tabular}




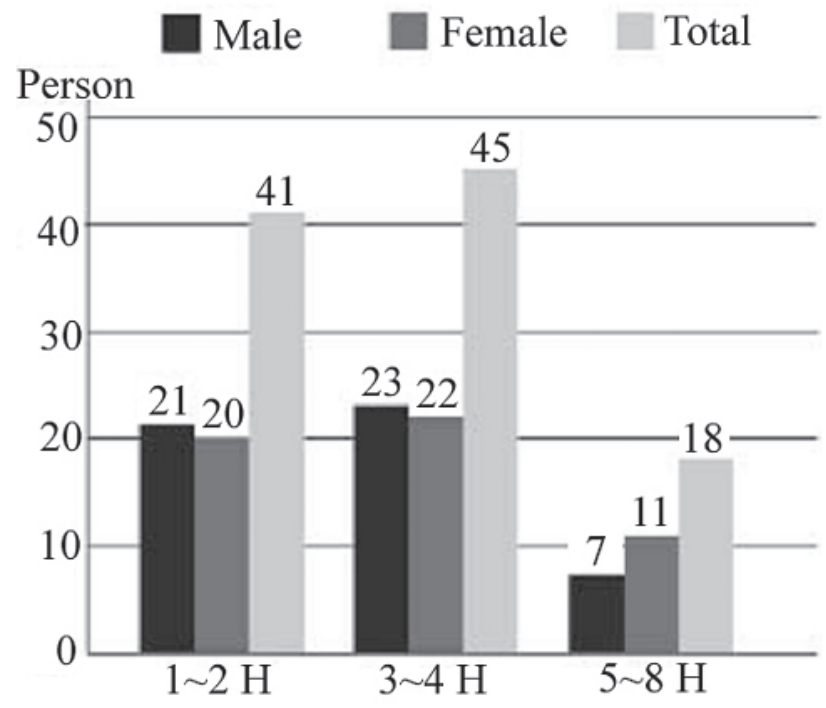

Fig.2. Leisure Time Distribution

education level.

\subsection{Detailed Investigation}

The contents of the investigation include: daily leisure time, leisure forms, leisure sites, reasons for choices, and motivation of leisure. These are illustrated in the figures as follows:

From Fig.2., we can see that males have a bit more leisure time than females. Also, daily leisure time has increased drastically: the majority of people have 3 4 hours for leisure every day.

Fig.3. shows that television and broadcasting occupies the first place. On the other hand, with a lack of suitable exercise fields, the frequency of physical exercise is only one third of the first activity. Another noticeable point is that internet use has rapidly gained popularity among young people. The latest data from CNNIC $^{2}$ shows that by January 2005 , the Chinese Internet population had grown to 94-million and 41.6-million computers are connected to the Internet. Generally speaking, static and individual activities are the majority of the people's daily leisure activities. Which do not aid in recovery from daily stress, tiredness, and fatigue, and do not encourage communication among people. The categories of Shanghai inhabitants' leisure activities are much less than that of western countries, especially active sports, such as bowling, golf, diving, rock climbing, etc. These sports are far from affordable for the common people. They still belong to the high-income upper-class. Chinese modern leisure life is in its beginning stages, and still keeps to traditional forms. There is a definite demand for additional possibilities and forms of leisure activities, to help make the average citizens spare time richer and more colorful.

As presented in Fig.4., it can be seen that within the urban outdoor leisure space, inhabitants' requirements for public green space is the most needed. In addition, the leisure sites that people can actually make use of are scarce, despite the categories or the amount. Most

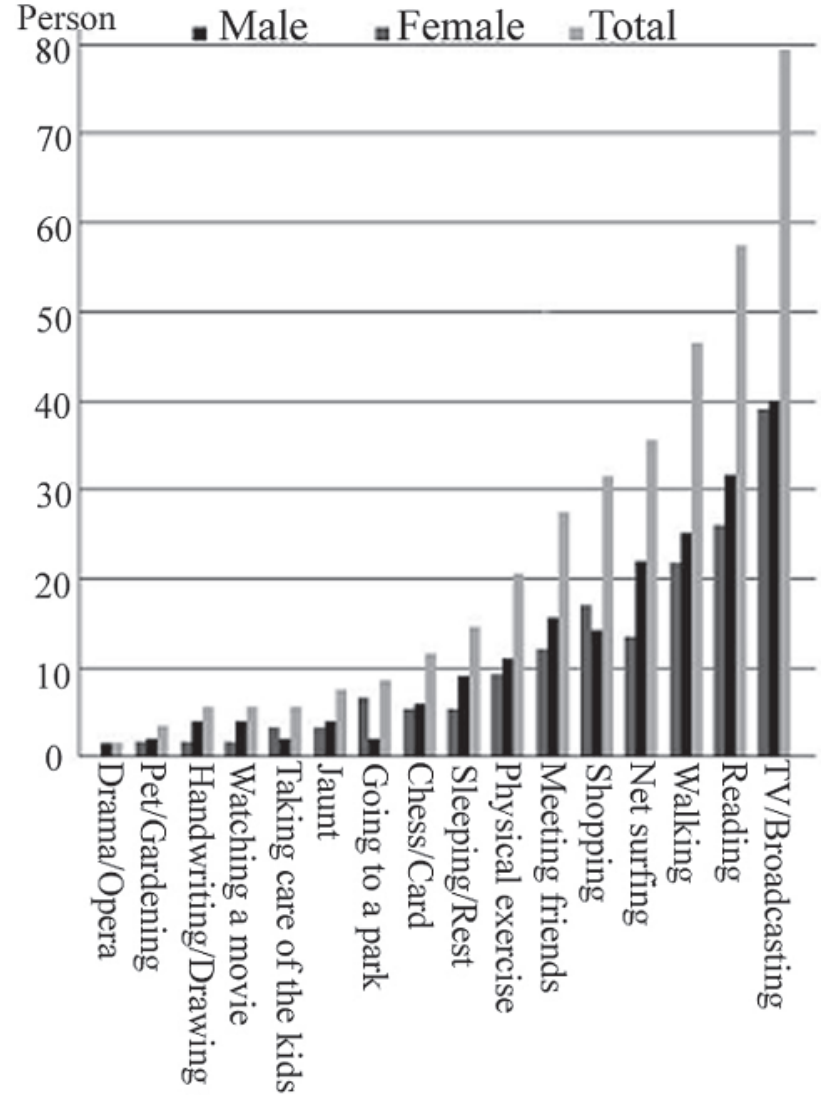

Fig.3. Leisure Activities

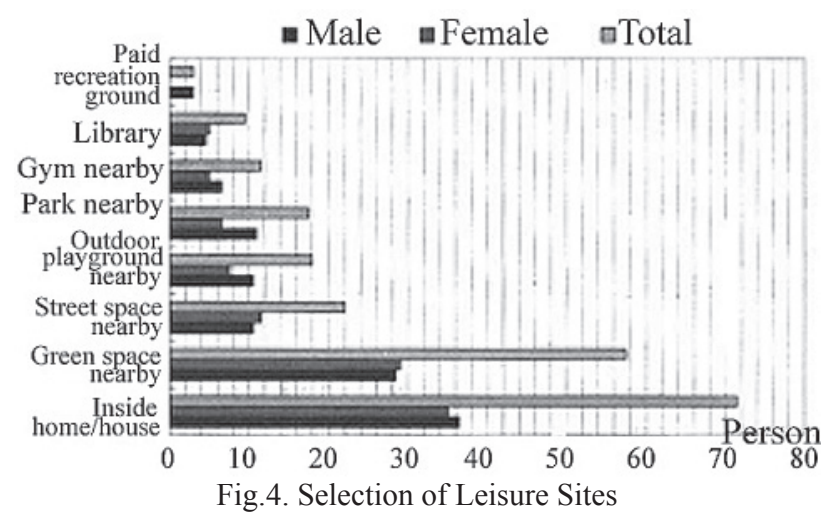

of the people's daily leisure activities are carried out in the home. The living area per person in Shanghai has increased to $13.8 \mathrm{~m}^{2}$, but available living space in the city is still much more limited than that of western countries.

In the near future, the amount of living space per person will increase very little in Shanghai, and the leisure activities that inhabitants have access to at the moment are still very ordinary. Also, the advanced sites have not been discovered by many of the subjects yet. Due to this, public leisure space should be enlarged and improved to deal with this issue. The increase in public space will motivate people to go out in their spare time and participate in activities that are conducive to good health.

Even though the current facilities are better than nothing, it should be noted that in the inquiry, we found most individuals using current leisure sites were not doing so because they favored the design of the site, but because of proximity and ease of access. We 

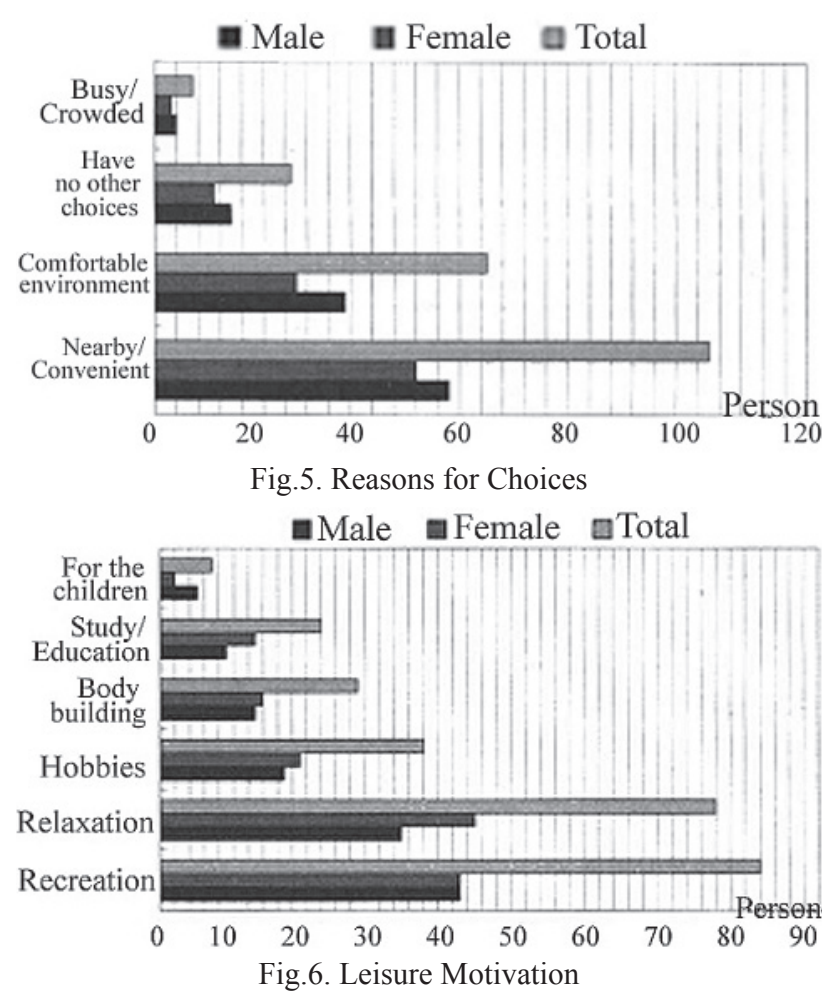

also discovered that the "Comfortable environment" question in the survey cannot be given too much weight, due to the fact that there isn't a decent variety of public space to choose from, and therefore a real comparison of sites is not possible. In this case "no comparison" can be interpreted as "no appreciation".

As shown in Fig.6. above, recreation and relaxation are still the two main motivations for leisure. In our investigation, we noticed another phenomenon: part of the parents' motivation for participating in leisure activities was to accommodate the needs of their children. Most parents interviewed would give attention to their own leisure needs providing that the children were satisfied first. Despite this condition, the facilities for children and juveniles are in need of improvement, which is a little embarrassing for the parents after stating such preferences.

The current society should theoretically be better motivated to provide excellent facilities for children. However, the common perception is that most children in China are so busy with their studies after school, that they don't have time to play outside anyway. This perception doesn't help the situation, but it is present, and cannot be excluded.

From Figs. 7 and 8, we could summarize that the majority opinion concerning the amount of leisure sites is that there are not enough. Because they are so small in number, their distribution cannot be balanced and this inconveniences those in distant neighborhoods. Aside from this, the ticket-fees of some sites are too expensive, and others are over-used and lack maintenance. Another opinion is that the current facilities lack multifunctionality, because the outdoor public leisure facilities industry in this region is in its early stage. There are other

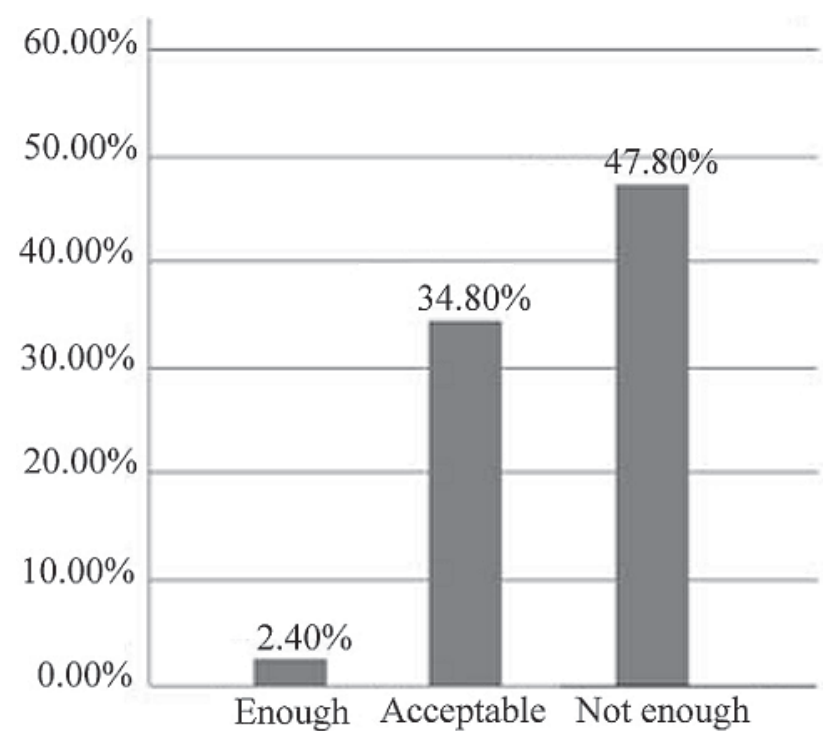

Fig.7. Opinions Concering the Amount of Leisure Sites

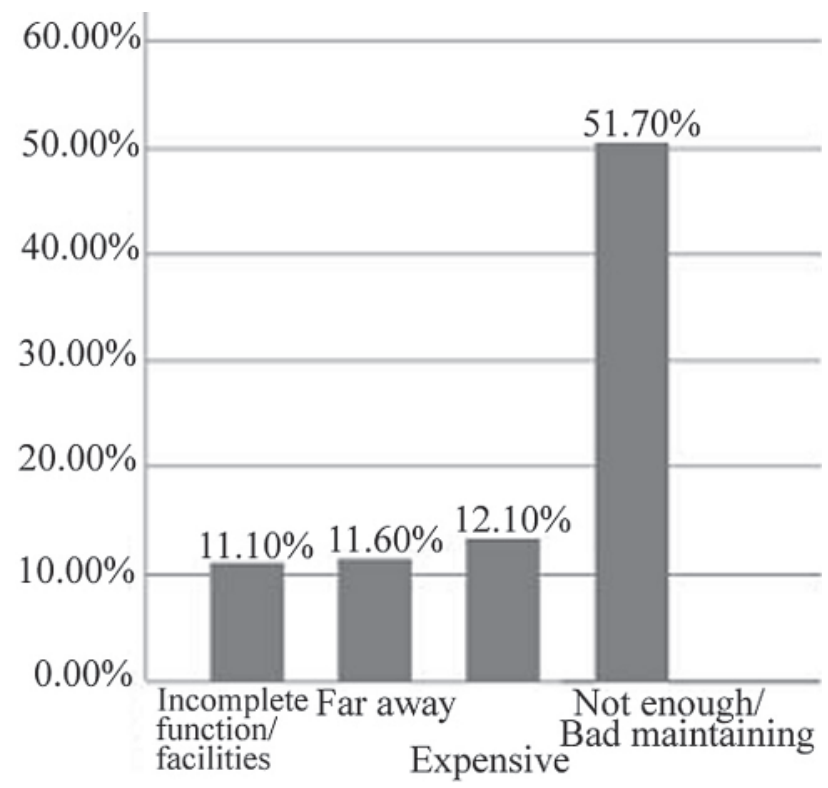

Fig.8. Main Problems of Leisure Sites

reasons for this shortcoming as well; for example lack of experience and funding. This problem can be solved by paying attention to current shortfalls, and increasing available capital for projects.

\subsection{Suggestions from Interviewees}

In the inquiry, the people provided us with a considerable assortment of suggestions. We managed to divide them into categories in Table 7.

\section{Conclusion}

Again, this study was initiated to clarify the significance of urban green open space by obtaining data on, and illustrating details concerning Shanghai urban inhabitants' daily leisure activities and sites. By means of the questionnaire taken in the area around People's Square in Shanghai, together with the statistics and analysis, we draw conclusions as follows:

(1) Leisure standard:

The present Shanghai urban inhabitants have a 
Table 8. Suggestions from Interviewees

\begin{tabular}{|c|c|}
\hline Category & Interviewees' suggestions \\
\hline $\begin{array}{c}\text { Traffic } \\
\text { and } \\
\text { distribution }\end{array}$ & $\begin{array}{l}\text { "The transportation situation should be more } \\
\text { convenient." } \\
\text { "I planned to go there, but have not. It is too far, } \\
\text { half an hour's drive is the best." } \\
\text { "Convenient transportation is a chief point, and } \\
\text { a comfortable environment is another." } \\
\text { "There is no field around my house for me to do } \\
\text { exercise." } \\
\text { "The sites that are small-scale and easy to reach } \\
\text { are too few." }\end{array}$ \\
\hline Expenditure & $\begin{array}{l}\text { "I hope there are some sites for low income } \\
\text { people." } \\
\text { "We need places that are totally free." } \\
\text { "The transportation expenses should suit the } \\
\text { common people's standards, so that we can go } \\
\text { there at any time." }\end{array}$ \\
\hline $\begin{array}{l}\text { Green } \\
\text { space }\end{array}$ & $\begin{array}{l}\text { " "Lack of shady trees." } \\
\text { "Forestation and management should be greatly } \\
\text { enhanced." } \\
\text { "Lack of lawn and shadow, it is too hot in } \\
\text { summer." }\end{array}$ \\
\hline $\begin{array}{c}\text { Age } \\
\text { difference }\end{array}$ & $\begin{array}{l}\text { "Most of our family's activities are focused on } \\
\text { the child, I hope the designer will take this point } \\
\text { into account." } \\
\text { "No place for the kids to play." } \\
\text { "The children's areas are too few." } \\
\text { "Increase the areas for the elderly." } \\
\text { "There is a center for the elderly, but it is too } \\
\text { far." } \\
\text { "The planning of the facilities should be more } \\
\text { reasonable; at present, the facilities for children } \\
\text { and the elderly are not enough, and facilities } \\
\text { located in the uptown area are not enough." } \\
\text { "The facilities are for children, adults can not } \\
\text { use them." } \\
\text { "The places for young people to date are too } \\
\text { few, and air pollution is a serious problem." }\end{array}$ \\
\hline $\begin{array}{l}\text { Management } \\
\text { and multi- } \\
\text { functionality }\end{array}$ & $\begin{array}{l}\text { "The body-building facilities are scarce, and are } \\
\text { not repaired after being damaged." } \\
\text { "There is a lack of street lamps and telephones } \\
\text { for public use, and personal safety is not } \\
\text { assured." } \\
\text { "There is no place for you to get something to } \\
\text { drink, and the toilet is hard to find." } \\
\text { "Enhance the management's work, combine it } \\
\text { with the citizen's education." } \\
\text { "I live in the residential area of our factory, } \\
\text { nobody takes charge of the environment, so the } \\
\text { condition is much worse than the downtown } \\
\text { area." } \\
. . . . .\end{array}$ \\
\hline others & $\begin{array}{l}\text { "The site should be quiet and comfortable and } \\
\text { not make people feel lonely." } \\
\text { "I hope there is an advanced court for gateball" } \\
\text { "Increase the amount of park attendants in order } \\
\text { to clean the ground in time." } \\
\text { "The core flourishing area should fully embody } \\
\text { the idea of humanism." }\end{array}$ \\
\hline
\end{tabular}

relatively adequate amount of daily leisure time (about 3 hours per day) and an adequate amount of disposable income. The people's consciousness and desire for leisure and recreation is high. However, the categories of leisure activities are small and most of them are traditional and static in form. In all, compared to western developed countries, the leisure standard of Shanghai urban inhabitants are still in their early stages, but have enormous potential.

(2) Leisure sites:

The amount of present day Shanghai outdoor leisure sites fall short of requirements, and there is an imbalance in site distribution. The mainstream of outdoor leisure sites should be low in cost or free. Public green open space, such as public parks, are the most popular sites. There are two points worthy of more attention when considering the design of future green open spaces in Shanghai: enhance the amount of greenery and take into account differences in age among users. Finally, a management and maintenance system should be perfected.

(3) Future research topics:

-The usage and evaluation system of urban green open space.

- How to combine Shanghai's originality with western style.

- Compare Shanghai data about people's attitudes towards leisure activities and sites with that of other countries.

- How to develop green space without destroying the traditional residential areas.

\section{Endnotes}

(1994) Zhong Hua Ren Min Gong He Guo Lao Dong Fa. (Eng. Labor Laws of P. R. China, 1994.) "3rd. ...laborer has the right of rest and vacation...", "36th. Implement the Man-hour System of not exceeding 8 hours a day and 44 hours a week".

2 CNNIC: China Internet Network Information Center.

3 Age groups: Children: <15 (not including 15); Adolescent: 15-22; Young Adult: 23-40; Mature Adult: 41-60; The Elderly: >60 (not including 60).

\section{References}

1) Anne, V. and Stéphanie, B. others (2005) Leisure Time Physical Activity and Health-related Quality of Life, Preventive Medicine, Volume 41, Issue 2, August 2005, pp.562-569

2) W. H. Martin and S. Mason(1976) Leisure 1980 and beyond, Long Range Planning, Volume 9, Issue 2, April 1976, pp.58-65

3) H. Leo Theuns (1989) Multidisciplinary Focus on Leisure and Tourism, Annals of Tourism Research, Volume 16, Issue 2, 1989, pp.189-204

4) Grant, C. and A. J. Veal, and Jiri Z. (2004) Free Time and Leisure Participation

5) Ma Jianye (2002) Cheng Shi Xian Xia Huan Jing Yan Jiu Yu She Ji. (Eng. Ma Jianye, 2002, Research and Design on Urban Leisure Environment)

6) (1984) Chou Yang Diao Cha Ji Ben Yuan Li, Lian He Guo Tong Ji Ju. (Eng. Spot Check Basic Theory. Statistics Bureau of the United Nations. 1984)

7) The Analects of Confucius, Spring and Autumn Period.

8) The 15th. Statistics Report of the Chinese Internet Development Status, 2005.1.

9) Shanghai Statistical Almanac, 2004. 